\title{
PJIEE
}

Premise: Journal of English Education and Applied Linguistics

https://fkip.ummetro.ac.id/journal/index.php/english

Pratiwi, Putri and Suhadi

\section{SHORT STORY AS A MEDIA FOR MOTIVATING STUDENTS' IMPROVEMENT IN READING}

\author{
Dwi Indah Pratiwi \\ Muhammadiyah University of Bengkulu \\ Dwiindahpratiwi7@gmail.com \\ Juita Putri \\ Muhammadiyah University of Bengkulu \\ juitaputri515@gmail.com \\ Agung Suhadi \\ Muhammadiyah University of Bengkulu \\ agungslecturer@gmail.com
}

\begin{abstract}
:
This study informs the use of short story as media for motivating students improvement in reading that is tested in third semester B class at Muhammadiyah University of Bengkulu, based on research in EFL students classrooms state, a good indicator of improved motivation and interest in reading can be used by the short story (Ceylan, 2016). This method in this research used experimental methods, based on the research conducted. The result showed there was an improvement in students' motivation in reading. The mean score of the pre-test was 67,64 . Then the mean score of the post-test is 94,11. There was an improvement in students' scores between pre-test and post-test, it is improved 39,13\%. It means the result of the test was satisfactory and show the best achievement. So, it can be concluded that improving students' motivation in reading by using short stories as media is improved. It means that this technique can be used by other researchers to improve the same reading skill.
\end{abstract}

Keywords: improvement, media, motivating, reading, short story, EFL students

\section{INTRODUCTION}

English is a foreign language in Indonesia. Therefore, it is hard for Indonesian students in learning English, especially reading text in a foreign language. The difficulties of Indonesian students in reading English text is supported by a varied analysis that shows the ability of Indonesian students 
in reading English texts were low (Syatriana, 2010, p.28). The success of students in learning is commonly supported by their knowledge from their reading as they will develop the information and find new information from reading that is associated with their studies through reading a book The students' interest in reading is important for their achievement (Anggraeni \& Turmudi, 2013). Finally reading is one of the most crucial processes when students are writing English scientific writing, particularly in the era of Industrial Revolution 4.0. (Turmudi, 2020)

The students' motivation in reading is important. According to Harmer (1983), motivation is an internal drive, which pushes someone to do or think about achievement. Motivation divided into two kinds, intrinsic motivation (comes from within, involved in activities of their own volition), and the last is extrinsic (motivation that is derived from external factors such as teacher ways of teaching, to need to the past exam, reward, and interest in the task). Motivation is a power coming from inside and outside the individual to do an action. Two kinds of motivation are considered as the most important in teaching EFL students because it comes from students and teachers.

EFL students are totally different and need a distinct motivation. Finding what motivates every student can facilitate students' improvement in reading. Someday the student does not have to inspire or bore to read some text in the English language. Students assume that interest in reading texts is still low, and it is hard to know. Besides that, they are doing not have the reading motivation to read. Reading Motivation is the psychological feature drives to read. Learning and implementing the conditions underneath that students are motivated to read is vital in the process of teaching and learning.

Reading is one hard activity for EFL students because reading involves a combination of abilities, Reading could be a multifarious method involving word recognition, comprehension, fluency, and motivation, Leipzig (2001). It learns. However, readers integrate these aspects to form that means from the written materials. Emerald (1932) in Ramlan (2002) says that reading is over a symbol recognition of graphic symbols of words. Its progressive comprehension of the meaning, ideas, and concepts are represented by a sequence of words. It includes seeing the word, recognizing the word to it is context. Reading is not an easy thing, it is not only getting meaning from word to word to understand what we read, but reading is a process of thinking, advanced intellectual process, and message of the text.

Premise Journal Vo. 9 No 1, April 2020, e-ISSN: 2442-482x, p-ISSN: 2089-3345, page 30-41 Copyright@20 by PJEE 
There are some ways often enforced in the teaching and learning process, one among them by using short stories as a genre of literature. By Imam Ja'far Al-Sadiq (Muslim scholar and philosopher) as cited in Suhadi (2018), "Literature is an artistic interpretation of the world life as a piece of life that has been given rules and meaning," Short story facilitate students in reading, and it may well be a lot of fun (Dari, 2020). A short story deals with vital components, All of those components take their role to form the story-wise and connected that build the story itself. They are theme, setting, plot, character, and point of view. Many studies addressed this issue specializing in motivating EFL students with the employment of literature (Brumfit \& Carter, 1991; Benton \& Fox, 1985; Bibby \& McIlroy, 2013). Researchers additionally gave recommendations that a short story is a perfect approach of introducing students to literature for motivation and improvement in reading.

Relating to those explanations above, EFL students have a low interest in reading. Thus, Hayashi (1999) counseled teachers to choose texts that stimulate students to read. So the difficulties of descriptive linguistics, vocabulary, and comprehension are often overcome. This is a way to create the students interested and motivated in reading English text.

As media for motivating students in reading, Media is an important thing in the teaching and learning process. "Several varieties of Media employed in the method of learning and teaching English like video, audio, picture story, film, and others. Generally, media for teaching will have a combination like animation. Some or all of the media organized into some coherent Program" (Mishra \& Sharma, 2004,p.4). Moreover, the story is anticipated to form the students fascinated by reading, is associated with reading and appreciating literature, Palardy (1997,p.7) explicit that students "will have the chance to develop insights and understandings of the cultures and other people of the world to develop their imaging and mental image abilities and to realize new views by testing their concepts with those found in books."

Using the short story as media for motivating students in reading is a very effective way. A short story could be an easier approach as media because it is simple, has the standard of being universal and story can permit the teacher to deal with the human matter. Arigol (2001) as cited in Hismanoglu (2005) listed the advantages of using the short story: "Short story has a simple and short characteristic." So, it makes the students' reading task easier because it is simple and short. Provide learners a more view of people and different cultures, needs a lot of attention and analysis helps students to be a creative and up the critical thinking skills, raise cultural awareness, degrade

Premise Journal Vo. 9 No 1, April 2020, e-ISSN: 2442-482x, p-ISSN: 2089-3345, page 30-41 Copyright@20 by PJEE 
students anxiety and helps them feel a lot of relaxing, is nice for multicultural context because English is a universal language, offers a fictional and interesting world.

The definitions of literature and motivation are often found. Varied sources have explained literature in varied ways in which. As an example, Mursal Esten as cited in Nopikasari, Safitri, \& Suhadi, (2018) stated that "literature shows the expression of literary facts as a manifestation of an artistic, art of human imaginative or society through language as a media."Which features a positive result on human life or social life. Literature is made public as writings whose value lies within the fantastic factor regarding the type or emotional result inside the Concise wordbook of Current English (2011)," And motivation is some kind of internal drive, which pushes someone to do or think about achievement by Harmer (1983).

When it involves motivation, Motivation divided into two kinds, intrinsic motivation, and extrinsic motivation. Intrinsic motivation is the variety of motivation that is animated by personal enjoyment, interest, or pleasure, participating in an activity because it is pleasant and satisfying to try to do. The opposite is extrinsic motivation, managed by reinforcement contingencies to attain some instrumental result, like earning a door prize or avoiding a penalization (Becker, McElvany, $\&$ Kortenbruck, 2010). Educators have admitted the importance of motivation as a key factor to improve reading ability or skill (Al-Nafisah, 2011).

In summary, literature involves emotional, attitudinal, and experiential factors, and then could motivate students to read (McKay, 1986). Therefore, literature is motivating because it deals with things, and also themes that the author thought-about important to deal with and the psychological feature result of the genuineness literary texts are inflated once the topics related to the learner's personal experience (Duff \& Maley, 2007). With the utilization of literature, learners could build new vocabulary similarly as they expand their understanding of words they already knew (Ono, Day \& Harsch, 2004). In the reading process, the learners should have good word recognition skills and implement some reading strategies such as identifying main ideas, making connections, questioning, inferring and predicting (Moreillon, 2007 as cited in Handayani,2013).

According to Harris and Sipay (1975), scanning and skimming techniques are types of reading techniques that require different approaches in achieving goals. Additionally, literature could facilitate students to own the habit of reading, and if students will develop the habit of reading particularly for enjoyment and interest, they'll increase confidence and fluency, and gain the habit of reading in an exceedingly foreign language (Brown, 2000).

Premise Journal Vo. 9 No 1, April 2020, e-ISSN: 2442-482x, p-ISSN: 2089-3345, page 30-41 Copyright@20 by PJEE 
Motivating students' reading by using short stories is very interesting because when the teacher explains about the short story, the students can give more attention to learn about it (Ceylan, 2016; Al-Nafisah, 2011). Another advantage that the short story has an independent existence, not like excerpts or chapters in novels, they represent complete units of meaning.

Also, short stories will encourage students since they will explore their feelings through experiencing people who happened within the stories, and that they are inspired to continue reading Elliott (1990) declared that literature is, "motivationally effective if students will genuinely have interaction with its thoughts and emotions, and appreciate its aesthetic qualities" (p.197). Moreover, using the short story will teach students to develop critical thinking Howie (1993) cited in Erkaya (2005, p.9). He explained more that teacher has the responsibility to assist students in developing their cognitive skill as "make judgments, be decisive, conclude, synthesize data or information, organize, evaluate, predict, and apply the knowledge.

Upon all reviewing processes, the current study is to investigate how short story as a medium for motivating students' improvement in reading. Therefore the research questions are:

1. What is the students' motivation in reading by the media of short story?

2. What is the score of the students' pre-test and post-test of reading by the media of the short story?

\section{METHOD}

\section{Design}

In this research, the researcher used a quantitative experimental method (Borg and Gall. 1983; Creswell, 2017) states that experimental research is the most reliable scientific study (most valid) because it is carried out by tight control of the confounding variables outside of the experiment. Experimental research is a special form of investigation which is used to determine what and how the variable is shaped relationship between one another or causality in the variable. According to the classic concept, experimental research to determine the effect of treatment variables. Consequently, an experimental research is a research method that is often done by researchers in education.

Premise Journal Vo. 9 No 1, April 2020, e-ISSN: 2442-482x, p-ISSN: 2089-3345, page 30-41 


\section{Participant}

The population in this study is the third-semester students of English language study programs of Universitas Muhammadiyah Bengkulu. The determination of this population is because one of them motivates students in increasing interest in reading, especially those who are studying extensive reading subjects at the university level, namely third-semester students. The population in this study is some students of class $3 \mathrm{~b}$ which consist of 17 students, This research was conducted at the Muhammadiyah University of Bengkulu in December 2019 in the odd semester.

\section{Data Collecting Technique}

The process of data collecting technique is set in the following procedures.

First, the researchers distributed a questionnaire to the selected participants. It was aimed at knowing the students' motivation in reading and how well the technique of teacher or lecturer in teaching reading. As all participants filled out the questionnaires and submitted it to the researchers.

Second, the researchers give a pre-test by preceding the following steps.

1. The teacher explained simply about the short story.

2. The teacher distributed the short story the Chapel to Students.

3. The students read the short story in 5 minutes.

4. The teacher designed the test and the question is multiple-choice.

5. The students answered the questions quickly.

6. Students submitted the paper of the test.

Finally, the teacher distributed a post-test by doing the following steps.

1. the teacher delivered a simple explanation about technique in reading.

2. the teacher divided learners into groups. Each group consists of 2-3 students.

3. All the students read the short story of the winepress in 5 minutes.

4. the students have 2 minutes to share the information about the short story with their partner.

5. The teacher distributed the test and the question is multiple-choice.

6. The students were to answer the question quickly.

7. The students submitted the paper of the test to the teacher.

All these stages are the process involved both researcher and participants of the study so that the data can be consolidated for further process called data analysis technique. 


\section{Data Analysis Technique}

The technique of the data analysis in this research, the researcher uses quantitative data, in analyzing data, the researcher got the average of student's motivation score per action in one cycle. It used to measure how well the student motivation in reading by using short story used this formula :

$$
\begin{aligned}
& \text { Mean }: \frac{\varepsilon x}{n} \\
& \text { X: individual score } \\
& \text { n: number of students }
\end{aligned}
$$

\section{RESULTS AND DISCUSSION}

The current study is to investigate the students' motivation, and the students' scores in

\begin{tabular}{|c|c|c|c|}
\hline Items & 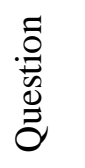 & 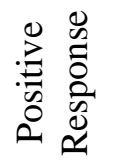 & 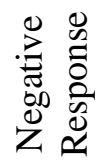 \\
\hline \multirow{2}{*}{ Attention } & Q3 & 9 & 8 \\
\hline & Q7 & 10 & 7 \\
\hline \multirow{3}{*}{ Relevance } & Q4 & 10 & 7 \\
\hline & Q5 & 10 & 7 \\
\hline & Q6 & 10 & 7 \\
\hline \multirow{2}{*}{ Confidence } & Q9 & 13 & 4 \\
\hline & Q10 & 11 & 6 \\
\hline \multirow{3}{*}{ Satisfaction } & Q2 & 11 & 6 \\
\hline & Q1 & 10 & 7 \\
\hline & Q8 & 13 & 4 \\
\hline TOTAL & & 107 & 63 \\
\hline MEAN & & 6,3 & 3,7 \\
\hline
\end{tabular}
reading; therefore the result is presented in the following table.

Table 1. Questionnaire of Students' Motivation in Reading

From the Guttman Scale analysis, To find out the percentage position of the answers obtained from the questionnaire then calculated first then placed in the range of percentage scales, 
"Yes" Answer Value: 1, Answer Value "No": 0, Converted in percentages, From Guttman Scale analysis, the point is less good above $50 \%-70 \%$, so it can be said that students' motivation and teaching techniques for reading by teachers are less good, with a percentage of $63 \%$.

Further, the students' score in reading consists of pre-test and post-test as presented in the following table. Both scores are combined in a grid to make it easy when comparing the evidence of the current study.

Table 2. Students' Reading Score in Pre-test and Post-test Score

\begin{tabular}{|c|c|c|}
\hline Students & $\begin{array}{c}\text { Pre- } \\
\text { test }\end{array}$ & $\begin{array}{c}\text { Post- } \\
\text { test }\end{array}$ \\
\hline 1 & 80 & 100 \\
\hline 2 & 70 & 80 \\
\hline 3 & 70 & 100 \\
\hline 4 & 80 & 100 \\
\hline 5 & 60 & 100 \\
\hline 6 & 70 & 90 \\
\hline 7 & 60 & 80 \\
\hline 8 & 70 & 90 \\
\hline 9 & 60 & 80 \\
\hline 10 & 80 & 100 \\
\hline 11 & 60 & 90 \\
\hline 12 & 60 & 100 \\
\hline 13 & 70 & 100 \\
\hline 14 & 70 & 100 \\
\hline 15 & 60 & 100 \\
\hline 16 & 70 & 100 \\
\hline 17 & 60 & 90 \\
\hline Total & 1150 & 1600 \\
\hline Mean & 67,64 & 94,11 \\
\hline
\end{tabular}

After getting the score of students per section, the researcher identified whether or not there was an improvement of students' reading skills from pretest average score in cycle 1 and cycle 2 .

The experimental class is a class that gets learning to read a short story as a medium for motivating students in reading. Before doing this class experiment gets the treatment by getting an explanation of the technique in reading and important element in the short story. The subject's experimental class is a third-semester student of the English study program as many as 17 students. Test results from the mean score in pretest are 67,64. it is the score of students' motivation in 
reading before they used short story techniques. furthermore, the mean score in the posttest is 94,11 . it is improved by $39,13 \%$.

\section{Discussion}

The current study is to investigate if a short story as a medium for motivating students' improvement in reading. For that reason, both current findings and previous evident are compared to find what it means.

Based on the data from the research above we get the result, the sample of this research is 17 students from the third semester of the English study program at the Muhammadiyah University of Bengkulu and this research is doing in there. The tests in this research were divided into pre-test and post-test to know the student motivating improvement in reading by using a short story. we directly observed in students sample classroom to know the motivation of the students in reading.

Meanwhile, the post-test is the last test that used to know the score is improve or not and compare the score with the pretest score. The research purpose is to know the improvement of motivating in reading with common technique and short story as a media. Besides that, the research is also to know the effectiveness of using a short story as a medium for motivating students improvement in reading.

Prior studies by Syatriana ( 2010), Anggraeni \& Turmudi (2013) showed that the students' motivation and scores improved, and thus the current study is consistent. It means that the findings of the current study have a positive sense and thus the implemented technique is applicable in EFL class.

\section{Conclusion}

Based on research findings of the current study carried out at the University of Muhammadiyah Bengkulu, it can be concluded. Firstly, that short stories are a good media to motivate students to improve their reading abilities because they can be seen from the found results. Secondly, that short stories can increase students' motivation in reading because short stories are very interesting to read. Therefore, students are shown that they can get high scores, especially in reading English. Student reading test results can be measured that students can increase their motivation in reading. increasing the average value of students from pre-test 67.64 to post-test is 
94.11, it means the percentage of student classes is $100 \%$ all students can improve their motivation in reading by using short stories.

\section{BIOPROFILE}

Dwi Indah Pratiwi is a student in the faculty of teacher training and education in the English study program at UM-Bengkulu. She is an active student in campus organizations, as part of campus ambassador. She has participated in several positive activities on campus. She is now pursuing a Bachelor of English Language Education at the Muhammadiyah University of Bengkulu. Corresponding email; Dwiindahpratiwi7@gmail.com

Juita Putri is a students in the faculty of teacher training and education in the English study program at UM-Bengkulu. She is an active student in campus organizations as a member of the Muhammadiyah Student Union Organization (Ikatan Mahasiswa Muhammadiyah). She has participated in several positive activities on campus. She is now pursuing a Bachelor of English Language Education at the Muhammadiyah University of Bengkulu. Corresponding email: juitaputri515@gmail.com

Agung Suhadi, SS., MA is an English lecturer in UM Bengkulu. His research interest in literature and linguistics study. He is very active to present his research at conference and seminar as well. Corresponding email: agungslecturer@gmail.com 


\section{REFERENCES}

Albert J. Harris and Edward R. Sipay. (1975). How to Increase Reading Ability,6th ed. New York: David Mckey Company, Inc.

Al-Nafisah, K. (2011). Saudi EFL students' reading interests. Journal of King Saud UniversityLanguages and Translation, 23(1), 1-9.

Anas, Sudjiono. (2008). Pengantar Statistik Pendidikan, Jakarta: Raja Grafindo Persada

Anggraeni, N. P. A. D., \& Turmudi, D. (2013). The comparison of students' writing descriptive text ability by using jigsaw and scaffolding technique in even semester at grade $\mathrm{x}$ state senior high school 1 Seputih Raman academic year 2012/2013. Premise: Journal of English Education, 2(1), 28-43.

Becker, M., McElvany, N., \& Kortenbruck, M. (2010). Intrinsic and extrinsic reading motivation as predictors of reading literacy: A longitudinal study. Journal of Educational psychology, 102(4), 773.

Benton, M., \& Fox, G. (1985). What Happens When We Read Stories?. 2006). Children's literature: Critical concepts in literary and cultural studies, 2.

Bibby, S., \& McIlroy, T. (2013). Literature in language teaching: What, why, and how. The language teacher, 37(5), 19-21.

Borg, W.R. \& Gall, M.D. (1983). Educational research: An introduction. Fourth Edition.New York: Longman.

Brown, R. (2000). Extensive Reading in the EFL Class.

Brumfit, C.J. and Carter R.A. (1991). Literature and Language Teaching. Oxford: Oxford University Press.

Ceylan, N. O. (2016). Using short stories in reading skills class. Procedia-Social and Behavioral Sciences, 232, 311-315.

Creswell, J. W., \& Creswell, J. D. (2017). Research design: Qualitative, quantitative, and mixed methods approach. Sage publications.

Dari, Y. W. (2020). Psychological Analysis in Jhon Updike's Separating. Journal of English Education, Literature and Linguistics, 3(1), 56-65.

Duff, A., and Maley, A. (2007). Literature. (Second edition). Oxford: Oxford University Press

Elliot, R. (1990). Encouraging reader-response to literature in ESL situations. ELT Journal, 44(3), 191-198.

Erkaya, O. R. (2005) Benefits of Using Short Stories in the EFL Context. Modern Language Journal, 67, 413-423.

Premise Journal Vo. 9 No 1, April 2020, e-ISSN: 2442-482x, p-ISSN: 2089-3345, page 30-41

Copyright@20 by PJEE 
Hamra, A., \& Syatriana, E. (2015). Developing a model of teaching reading comprehension for EFL students. TEFLIN journal, 21(1), 27-40.

Handayani, P. M. (2013). Using Children Short Stories to Enhance Students in Reading Comprehension. Journal of English and Education 1(1), 133-141

Harmer, J. (1983). The Practices of English Language Teaching. New York: Longman.

Harmer, Jeremy. (1991). The Practice of English Language Teaching. London: Longman.

Hayashi, K. (1999). Reading strategies and extensive reading in EFL classes. RELC Journal, 30(2), 114-132.

Hismanoglu, M. (2005). Teaching English through literature. Journal of Language and Linguistic Studies, 1(1), 53-66.

Leipzig, D. H. (2001). What is reading? Reading Rockets.

Literature. (2020). Oxford Reference. Retrieved on May 10, 2020 from https://www.oxfordreference.com/search?q=Literature\&searchBtn=Search\&isQuickSearch=true

Mason, Jana. M. and Au, Kathryn. H. (1990). Reading Instruction for Today. USA: Harper Collins Publishers.

McKay, S. (1986). Literature in the ESL Classroom in Literature and English Language Teaching, Christopher J. Brumfit, and Ronald A. Carter (eds.) Oxford: Oxford University Press, 191198.

Meltzer, D. E. (2002). The relationship between mathematics preparation and conceptual learning gains in physics: A possible "hidden variable" in diagnostic pretest scores. American journal of physics, 70(12), 1259-1268.

Mishra, S.; \& Sharma, R. C. (2004). Interactive Multimedia In Education Training. United States of America: Idea Group Publishing.

Nopikasari, N., Safitri, A., \& Suhadi, A. (2018). Analysis word classes in selected poems by Allan Alexander Milne. Premise: Journal of English Education, 7(2), 1-14.

Ono, L., Day, R. and Harsch, K. (2004). Tips for Reading Extensively. English Teaching Forum Online, 42.04.

Palardy, J. M. (1997). „Another look at literature-based instruction.“ Education, 118(1), 67-70.

Ramlan. (2002). Improving Students Reading Motivation by Using Anecdote. Unpublished Thesis. Bengkulu: Universitas Bengkulu

Sudjana. (2002). Metodata Statistika. Bandung: PT Tarsito.

Turmudi, D. (2020). English Scholarly Publishing Activities in the Industrial Revolution 4 . 0 : What, Why , and How? ELTEJ, 3(1), 52-62. Retrieved from http://journal2.uad.ac.id/index.php/eltej/article/view/18

Premise Journal Vo. 9 No 1, April 2020, e-ISSN: 2442-482x, p-ISSN: 2089-3345, page 30-41 